УДК 37.07.09.011-027.561-047.22

UDC 37.07.09.011-027.561-047.22

DOI: $10.31475 /$ ped.dys.2020.29.09

ІРИНА МИЩИШИН,

кандидат педагогічних наук, доцент

(Україна, Львів, Львівський національний університет ілені Івана Франка, вул. Туган-Барановського, 7)

IRYNA MYSHCHYSHYN,

Candidate of Pedagogical Sciences, Associate Professor (Ukraine, Lviv, Ivan Franko National University of Lviv,

Tuhan-Baranovskoho St., 7)

ORCID: 0000-0003-2740-8092

ХРИСТИНА КАЛАГУРКА,

кандидат педагогічних наук

(Україна, Львів, Львівський національний університет ілені Івана Франка, вул. Туган-Барановського, 7)

KHRYSTYNA KALAHURKA,

Candidate of Pedagogical Sciences

(Ukraine, Lviv, Ivan Franko National University of Lviv,

Tuhan-Baranovskoho St., 7)

ORCID: 0000-0003-3179-4694

ОРЕСТ МИЩИШИН,

кандидат фбізико-математичних наук, доцент

(Україна, Львів, Львівський національний університет імені Івана Франка,

вул. Коперника, 3)

OREST MYSHCHYSHYN,

Candidate of Physical and Mathematical Sciences, Associate Professor (Ukraine, Lviv, Ivan Franko National University of Lviv, Kopernyka St., 3)

ORCID: 0000-0001-5225-828X

\title{
Операційно-діяльнісні компетенції менеджера освіти
}

\section{Operating and Activity Competence of the Education Manager}

У статті обгрунтовано, що успішна діяльність освітньої установи є наслідкол ефбективної діяльності керівництва. Охарактеризовано особливості реалізацї операційно-діяльнісної компетенцї̈ й практичних улінь у процесі застосування різноманітних управлінських технік: управління через делегування, винятки, ціль, результати, конфблікти, нагляд і розпорядження, мотивацію, інновації, комунікування, інвігіляцію, контроль.

Констатовано, що практичні уміння керівника фборлуються в процесі профбесійної підготовки ц̌ вдосконалюються в уловах активної й творчої професійної діяльності. Різноплановість завдань $i$ фбункиій профбесійної діяльності керівника, зумовлена сучасними вимогами й контекстали відображаються у появі нових елелентів операційно-діяльнісної компетенцї, вдосконаленні дискретних умінь й систелних комплексів, прийомів майстерності управлінця.

Ключові слова: профбесійна компетентність; менеджер освіти; управління освітою, операційно-діяльнісна компетенція; практичні уління.

The attention is paid to the modern processes of the updating of a social-cultural mission of education, which cause a change of the educational paradigm and as a result of the contents and ways of the activity of modern educational institutions.

It is determined that an activity competence of a manager is essential on all the levels of leader's work: planning, conducting, motivating, control, estimating of work of all the objects of the administrative process. It includes special technological skills of the organisation of a managerial process, taking decisions, putting right team's work, environment of upholders, providing conditions for the dividing of duties and delegacy of authority, conducting of a systematic and opportune control on all the levels, consolidation of a democratic style of guidance, achieving of collective leadership and 
participation. The peculiarities of the realization of the operating and activity competence and practical skills are clarified in the process of applying different managerial techniques: guidance via delegacy, exceptions, aim, results, conflicts, control and direction, motivation, innovations, communication, invigilation.

On the basis of systematization and generalization of the material mentioned above, the essential role of operating and activity component in the system of professional competence of a manager of education is stated. Practical skills of a leader are formed in the process of a professional preparing and are improved under the conditions of active and creative professional activity. The diversity of the tasks and functions of the professional activity of a manager is caused by modern demands and it is reflected in the appearance of new forms of the operating and activity competence, improvement of discrete skills and systematic complexes, modes of a leader's mastery. The determination of a spectrum of the operating and activity competence is essential for the organization of a qualitative preparing of the future expertsleaders in the educational sphere.

Key words: professional competence, manager of education, education management, operating and activity competence, practical skills.

Вступ / Introduction. Модернізація соціально-культурної місії сучасної освіти зумовлюе нові вимоги до організації діяльності освітніх установ. Зміна пріоритетів відображена у концептуальних засадах сучасної освітньої парадигми. Ї̈̈ основними характеристиками е вихід за межі знаннєво-орієнтованої організації освітнього процесу, набуття суб’єктами навчання комплексу комунікативних, інформаційних, загальнокультурних, соціальних компетенцій, необхідних для самореалізації в сучасному суспільстві, прищеплення загальнолюдських цінностей, формування активної життевої позиції, здатності й потреби навчатися впродовж життя. Внаслідок таких викликів середовище нинішньої школи активно трансформуеться у простір виховання вискоосвічених, активних представників громадянського суспільства.

Успішне функціонування освітніх установ значною мірою залежить від ефективності діяльності керівника. Праця управлінця у світлі окреслених завдань та сучасних реалій: розширення ринку освітніх послуг, динамічних соціально-культурних змін, насиченості інформаційного середовища набувае нового характеру й вимагае опанування якісно новим рівнем фахової компетентності, стратегічним баченням перспектив, здатністю до педагогічної творчості, прагненням до розвитку та інновацій.

Аналіз складових професійної компетентності сучасного керівника освітньої сфери дає можливість визначити різноманітні компоненти, що охоплюють психологічну готовність, комплекс особистісних якостей та здібностей, систему загальних і спеціальних знань, уміння та навички практичної управлінської діяльності та ін. Серед них особливої уваги заслуговують складові організаційно-діяльнісного компонента, що мають безпосередній вияв у повноті реалізації принципів, виборі та застосуванні методів, технік, стратегій і прийомів управлінської діяльності на всіх етапах цього процесу.

Мета та завдання / Aim and Tasks. Метою статті е визначення та аналіз операційнодіяльнісних компетенцій сучасного менеджера освітньої сфери.

Завдання дослідження: охарактеризувати поняття професійна компетентність менеджера освітньої сфери, визначити місце операційно-діяльнісних компетенцій в системі професійної компетентності, проаналізувати їх сутність та умови успішного застосування і розвитку.

Методи / Methods. Методи дослідження: порівняння, систематизація, узагальнення даних психолого-педагогічної літератури, досліджень теорії й практики управління в освітній сфері; наукова інтерпретація сутності професійної компетентності менеджера освіти, аналіз змісту операційно-діяльнісного компонента.

Результати / Results. На підставі аналізу результатів наукових досліджень сучасні вчені констатували низку факторів, які на їхню думку, впливають на розвиток освітнього простору сучасної школи. Такими факторами вчені вважають: «наявність стратегії інноваційного розвитку школи, готовність учителя до інноваційної діяльності, сприятливі соціально-психологічні умови для інноваційних змін, ресурсне забезпечення інноваційних змін, професійну компетентність менеджерів шкільної освіти та відповідно функціональну ефективність усіх суб'єктів навчальновиховного процесу» (Вознюк Л., 2013).

$\mathrm{У}$ поданому переліку можна простежити чіткий наголос на інноваційності та готовності до змін, наявності стратегії розвитку закладу, що передбачае зміни і використовуе їх позитивний потенціал, а також фрункціональну спроможність менеджера, його операційно-діяльнісні компетенщії. Очевидно, що спрямованість і готовність до змін створюе передумови для динамічних перетворень й розвитку освітньої установи, дає можливість уникнути консервативності, яка неминуче призводить до стагнації й занепаду. Водночас прогресивні зміни не можуть відбуватися 
хаотично і безсистемно, для їх втілення необхідна розробка концептуальних засад і стратегічного планування. Управлінська стратегія розвитку навчальної установи базуеться на, так званому, організаційному баченні керівника.

Успішність організаційного бачення обумовлене виконанням низки вимог:

- «воно має бути пов'язане з конкретною освітньою організацією у конкретному часі;

- його слід обирати з інших можливих бачень розвитку освітньої організації як таке, що найбільше відповідае запитам, освітнім і соціально значущим потребам та інтересам учнів, їхніх батьків;

- воно має відображати щирі наміри й зобов'язання керівника як лідера;

- воно мае бути привабливим для персоналу, вмотивовувати його діяльність;

- воно повинно стати баченням усього колективу освітньої організації;

- воно може бути розвинуте й оцінене через якийсь час внаслідок зміни ресурсів або потреби» (Топузов О., \& Калініна Л., 2015).

Описані вимоги до розробки організаційної стратегії освітньої установи чітко узгоджені 3 вимогами до керівника освіти, які обтрунтовані сучасним трактуванням змісту освітнього менеджменту, як галузі, що визначае сукупність принципів, форм, методів управління педагогічними системами та педагогічним персоналом, базованих на наукових засадах.

Отож, виходячи із визначення менеджменту, керівник навчального закладу XXI ст. має:

- прогнозувати позитивне майбутне і формувати дух позитивних змін;

- забезпечувати відкрите керівництво;

- вивчати інтереси й потреби суспільства, щоб ставити нові цілі;

- організовувати роботу колективу на досягнення поставлених цілей;

- забезпечувати наявність різних ресурсів для якісного досягнення цілей;

- постійно вчитися і стимулювати до цього колег (Жигірь В., 2011).

Наведений перелік містить найбільш значимі характеристики менеджера освіти, які формують, так звані, рушійні передумови прогресивних реформаційних управлінських процесів. Відтак, можна зауважити, що значну увагу в професійній компетентності керівника, звернено на фонкціональну ефективність, а саме практичну спроможності управлінців. Наголос на важливості практичних умінь можна також простежити, здійснивши аналіз основних аспектів професійної компетентності менеджера шкільної освіти, визначених сучасними науковцями. Це поняття дослідники визначають доволі різнопланово. Зокрема, Л. Вознюк у професійну компетентність менеджера освіти зараховуе:

- «знання та розуміння природи управлінської праці та процесів менеджменту;

- знання посадових та функціональних обов'язків менеджера освіти;

- уміння використовувати інформаційно-комп'ютерні технології та інші засоби комунікацій, необхідні у процесі управлінської праці;

- людинознавча компетентність;

- володіння мистецтвом налагодження зовнішніх зв'язків;

- здатність до самооцінки, уміння робити правильні висновки» (Вознюк Л., 2013)

За міркуваннями В Жигірь, професійна компетентність менеджера освіти охоплюе такі ланки: загальнокультурну, комунікативну, психолого-педагогічну, управлінську та стратегічну (Жигірь В., 2011). У дослідженнях Т. Іванової встановлено змістові складові професійної компетентності керівника освітньої установи: спеціальні, загальні, особистісні, організаційні, комунікативні компетенції (Іванова Т., 2012).

Аналізуючи твердження науковців, можна констатувати обов'язкову присутність в переліку складових компетентності сучасного менеджера освітньої сфери організаційно-управлінських умінь, сутність яких передбачає психологічну готовність й здатність налагоджувати ефективну практичну діяльність. Така діяльнісна компетенція менеджера $е$ необхідною на всіх етапах роботи керівника: планування, здійснення, мотивування, контроль, оцінювання роботи усіх об’ектів управлінського процесу. Вона охоплюе спеціальні технологічні уміння організації управлінського процесу, прийняття рішень, налагодження командної роботи, дотримання управлінських принципів, формування атмосфери співробітництва, середовища однодумців, забезпечення умов для розподілу обов'язків й делегування повноважень, здійснення систематичного й своєчасного контролю на усіх рівнях, утвердження демократичного стилю керівництва. досягнення колегіальності й партисипативності.

Складові операційно-діяльнісного компонента, на думку, Д. Ханта та Р. Осборна, є основними рисами керівника, необхідними для досягнення ним кар'ерного успіху. У цьому компоненті вони визначають такі навички:

- «концептуальні навички - здатність аналізувати та розв'язувати комплексні проблеми;

- навички планування та організації - здатності обирати напрям діяльності та концентрувати 
ресурси для досягнення цілей;

- навички прийняття рішень - здатність використовувати інформацію та логіку для пошуку альтернативних рішень» (Мармаза О., 2007).

Операційно-діяльнісний компонент охоплюе системні та дискретні уміння. Їх реалізація найбільш повно знаходить вияв у втіленні певних управлінських технік. При здійсненні практичних дій відбувається не тільки тренування чи вдосконалення конкретних умінь, а також формуються більш складні форми, які можна назвати синтезованими прикладними управлінськими конструкціями. Аналіз різноманітних управлінських технік дає можливість описати різноманітні компетенції операційно-діяльнісного компонента продесійної компетентності керівника освітньої сорери.

До найбільш часто вживаних управлінських технік, сучасні науковці зараховують: управління через делегування, винятки, ціль, результати, конфлікти, нагляд і розпорядження, мотивацію, інновації, комунікування, інвігіляію, контроль (Plewki Cz., Bednarczyka H., 2008). Розглянемо сутність цих технік та спектр практичних умінь, які будуть актуалізовані в процесі їх здійснення.

Управління через делегування. В основі цієї техніки закладено принцип делегування управлінських повноважень від керівника підлеглим. Тобто рішення можуть бути прийняті, як на найвищому, так і на найнижчому рівнях. Техніка спрямована на те щоб працівник діяв самостійно в межах переданих йому повноважень. Рішення приймаються тільки там де це логічно повинно мати місце, а саме в місцях виникнення проблем. Завдяки цьому керівник звільняється від значної частини рутинної праці й може більше часу присвятити управлінню, внаслідок чого покращується соціально-психологічний клімат організації. Виважене застосування техніки делегування повноважень, відповідальності суттево активізуе i мотивуе працівників, яким передано повноваження. Найбільшою мірою ця техніка сприяе фрормуванню навичок аналізу потенційних можливостей підлеглих, визначенню меж їх компетентності, постановку посильних завдань, прийняття зважених рішень, створенню в середовищі школи атмосфери довіри й партнерської співпраці.

Управління через винятки. Основою ціеї техніки е засада винятків. Вона полягає в тому, що керівник повинен втручатися в роботу підлеглих тільки у виняткових випадках. Цю техніку характеризує спрощення процесу управління, вилучення керівника 3 рутинної роботи, ідентифікацію працівників із завданнями і чіткий поділ відповідальності. Базовою проблемою в окреслених умовах є питання визначення виняткових ситуацій i контроль результатів їх розв'язання. Застосування ціеї техніки не достатньо мотивуе працівників й більше того навіть обмежує можливості їх розвитку, у тих випадках, коли керівник переймає розв'язання цікавих проблем, а також функції нагляду і контролю. Основними практичними уміннями для реалізації ціеї техніки стають аналіз управлінського процесу, визначення ризиків, прийняття рішень в неординарних умовах.

Управління через ціль. Найбільш популярна сьогодні техніка. Полягає у визначенні цілей, які мають бути зреалізовані в окресленому періоді й мають провадити до узгодження потреб працівників 3 потребами організації. В цій техніці основою є слушна засада, що всі члени організації повинні чітко розуміти й долучитися до досягнення спільної мети, яку часто називають місіею організації. Управління через ціль спрямоване на чітке розуміння членами цілей організації, розвиток ініщіативи, уможливлюе коригування допущених помилок, а також забезпечуе ідентифрікацію працівників з місією організації. Застосування цієї техніки зумовлює те, що на перший план праці керівника виходять завдання, які вимагають концептуальної праці й відповідно навичок планування, організації і підтримки, здійснення аналізу, допомоги підлеглим у практичній реалізації цілей.

Управління через результати. Техніка містить багато схожих елементів з управлінням через ціль. Опираеться на засаду систематичного уточнення планованих цілей як інструменту управління, що в результаті вимагає координації децентралізованих рішень. Управління спрямоване на результати передбачає, що цілі не мусять бути узгоджені з працівниками, лише доведені до їх відома. Ця методика передбачає, що кожна людина хоче досягти успіху, усі працівники здібні та доброзичливі й більшість з них хоче взяти на себе відповідальність і прагне отримати задоволення від роботи. В такому контексті найціннішим є творчий потенціал та ініціативність. Від керівника вимагаються вміння здійснювати демократичне управління, гнучкість, готовність до співпраці, турбота про результати, прояв довіри до підлеглих, делегування відповідальності й створення можливостей для досягнення ними успіхів.

Управління через конфблікт. Основою цієї техніки є твердження, що конфлікти не є виключно проявом патології організації, а також відіграють і позитивну роль. Управління через конфлікт не передбачає цілеспрямоване їх створення, а застосування умінь аналізу конфліктних ситуацій, вибір найбільш оптимальних прийомів і стратегій їх розв'язання, стеження щоб вони не набули 
небезпечних розмірів, надмірної ескалацї, були під контролем. Конфлікти можуть бути вирішені у партнерській взаємодії на засаді компромісу або консенсусу. Сторони можуть краще зрозуміти одна одну, обговорити протилежні погляди, зважити сильні сторони, знайти спільні шляхи порозуміння, оздоровити стосунки.

Управління через нагляд $i$ розпорядження. Техніка базована на авторитарному стилі керівництва, не передбачає делегування повноважень, тут присутній лише розподіл праці й нагляд керівника за виконанням розпоряджень. Власна ініціатива працівників не допускаеться. Практичні уміння керівника авторитарного стилю: чіткі вказівки, розпорядження, інструктування, своєчасна перевірка і контроль.

Управління через мотивацію. Техніка передбачае створення умов для задоволення матеріальних і психічних потреб працівників, а також стимулювання їх до кращої роботи через створення мотиваційних ситуацій. Мотивування до роботи полягає у використанні низки диференційованих індивідуальних засобів і інструментів, що спонукають до ефективної роботи на користь організації. Таким чином керівник формуе уміння визначення мотивації працівників, встановлення пріоритетів, розробки стимулів, а також створення різноманітних мотивувальних ситуацій, які спрямовані на індивідуальні потреби працівників.

Управління через інновацї̈. Полягає у впровадженні різних змін (повноважень, вдосконалень, інновацій) передовсім у найбільш важливих сферах діяльності. В організаціях, скерованих на зміни, інновації е беззаперечною необхідністю, які генерують позитивні тенденції підвищення ефективності. Передумовою розвитку є відмова від пасивності, формування навичок офенсивного стилю діяльності, який вимагае постійних зусиль і готовності до реагування на підставі аналізу поведінки кліентів і конкурентів.

Управління через комунікування. Полягае у побудові та вдосконаленні стабільної системи інформування команди про головні цілі, проблеми й труднощі організації, наміри керівництва, а також актуальне становище установи на ринку. Безпосередньою ціллю цієї техніки є покращення інформування команди, яке забезпечить створення клімату взаемної довіри поміж керівництвом і підлеглими. Більше того, це призведе до зміцнення мотивації та утвердження позитивної поведінки працівників на користь організації. Основні уміння, які необхідні для застосування ціеї техніки, лежать у площині технологій успішної комунікації, безбар'ерного спілкування, володіння невербальними засобами.

Управління через інвігіляцію. Техніка е формою контролю, поеднаною з обмеженням інтервенції керівництва. Інвігіляція полягае на дискретному й систематичному спостереженні роботи підлеглих. Розвиток подій повинен відповідати очікуванням керівника. Таким чином техніка вимагае систематичного контролю, перевірок, аналізу отриманих результатів, формулювання висновків, випрацювання рекомендацій. Інвігіляція мае високий мотиваційний потенціал, який полягае у спонуканні підлеглих до ефективної роботи. Працівники, за якими наглядають, поводять себе інакше ніж ті, які позбавлені контролю.

Управління через контроль. Передбачає комплексний і багатоаспектний контроль усіх ділянок діяльності організації. Охоплюе систему умінь планування матеріальних і фінансових завдань, уточнення напрямів діяльності, забезпечення необхідною інформацією, контролю i звітування про виконання завдання.

Обговорення / Discussion. У сучасних науково-педагогічних пошуках проблема формування та аналізу сутності компетентності фахівців займае одне з центральних місць. У руслі наукової розробки засад компетентнісного підходу значні напрацювання здійснили В. Бондар, О. Пехота, О. Пометун, В. Жигірь та ін. (Жигірь В., 2011). Питання професійної компетентності менеджерів освіти, специфіку їх фахової діяльності активно вивчали О. Мармаза, Т. Іванова, І. Шоробура та ін. (Іванова Т., 2012; Мармаза О., 2007). Водночас детальний аналіз прикладних аспектів професійної компетентності й майстерності керівників освітньої сфери залишається актуальним й потребуе різнобічного вивчення у світлі актуальних проблем організації сучасного освітнього середовища.

Висновки / Conclusions. На підставі систематизації та узагальнення вищевикладеного матеріалу можна констатувати вагоме значення операційно-діяльнісної складової у системі професійної компетентності менеджера освіти. Практичні уміння керівника формуються в процесі професійної підготовки й вдосконалюються в умовах активної й творчої професійної діяльності. Різноплановість завдань i функцій професійної діяльності керівника, зумовлена сучасними вимогами й контекстами відображаються у появі нових вимірів операційно-діяльнісної компетенції, вдосконаленні дискретних умінь й системних комплексів, прийомів майстерності управлінця. Визначення спектру операційно-діяльнісної компетентності важлива для організації якісної підготовки майбутніх фахівців-управлінців в освітній сфері. 


\section{Список використаних джерел і літератури:}

Вознюк, Л. (2013). Роль менеджера освіти в оновленні сучасної школи. Початкова школа, 11, 42-43 [in Ukrainian].

Жигірь, В. (2011). Особливості професійної компетентності менеджерів освіти. Молодь і ринок, 5 (76), 6469 [in Ukrainian].

Іванова, Т. В. (2012). Культура педагогічного менеджменту викладача ВНЗ непедагогічного профбілю. Київ: Педагогічна думка [in Ukrainian].

Мармаза, О. I. (2007). Менеджлент в освіті: дорожня карта керівника. Харків: Основа [in Ukrainian].

Олійник, В., \& Протасова, Н. (2011). Освітній менеджлент в уловах освітніх змін: навч. посіб. Луганськ: СПД Резніков В. С. [in Ukrainian].

Топузов, О., \& Калініна, Л. (2015). Організаційні стратегії як детермінанти розвитку організаційної культури. Сучасні тенденцї розвитку організаційної культури загальноосвітнього навчального закладу в інфборлаційнолу суспільстві. (с. 4-17). Київ [in Ukrainian].

Plewka, Cz., \& Bednarczyk, H. (Red.). (2008). Menedżer i kreator edukacji. Radom [in Polish].

\section{References:}

Vozniuk, L. (2013). Rol menedzhera osvity v onovlenni suchasnoi shkoly [The Role of the Education Manager in the Renovation of a Modern School]. Pochatkova shkola - Elementary school, 11, 42-43 [in Ukrainian].

Zhyhir, V. (2011). Osoblyvosti profesiinoi kompetentnosti menedzheriv osvity [Features of Professional Competence of Education Managers]. Molod i rynok - Youth and Market, 5 (76), 64-69 [in Ukrainian].

Ivanova, T. V. (2012). Kultura pedahohichnoho menedzhmentu vykladacha VNZ nepedahohichnoho profiliu Kyiv: Peda[A Culture of a Pedagogical Management of a University Teacher of Non-Pedagogical Profile]. hohichna dumka [in Ukrainian].

Marmaza, O. I. (2007). Menedzhment v osviti: dorozhnia karta kerivnyka [Management in Education: a Road Map of the Leader]. Kharkiv: Osnova [in Ukrainian].

Oliinyk, V., \& Protasova, N. (2011). Osvitnii menedzhment $v$ umovakh osvitnikh zmin [Educational Management in the Conditions of Educational Changes]. L. Kalinina (Red.). Luhansk: SPD Reznikov V. S. [in Ukrainian].

Topuzov, O., \& Kalinina, L. (2015). Orhanizatsiini stratehii yak determinanty rozvytku orhanizatsiinoi kultury [Organizational Strategies as Determinants of Organizational Culture Development]. Suchasni tendentsii rozvytku orhanizatsiinoi kultury zahalnoosvitnoho navchalnoho zakladu $v$ informatsiinomu suspilstvi (pp. 4-17). Kyiv [in Ukrainian].

Plewka, Cz., \& Bednarczyk, H. (Red.). (2008). Menedizer i kreator edukacji [Manager and Creator of Education]. Radom [in Polish].

Дата надходження статті: «24» вересня 2020 р.

Стаття прийнята до друку: «21» жовтня 2020 р.

Мищишин Ірина - доцент кафедри загальної педагогіки та педагогіки вищої школи Львівського національного університету імені Івана Франка, кандидат педагогічних наук, доцент

Myshchyshyn Iryna - Assistant Professor of the Department of General Pedagogy and Higher School Pedagogy of Ivan Franko National University of Lviv, Candidate of Pedagogical Sciences, Associate Professor

Калагурка Христина - доцент кафедри загальної педагогіки та педагогіки вищої школи Львівського національного університету імені Івана Франка, кандидат педагогічних наук

Kalahurka Khrystyna - Assistant Professor of the Department of General Pedagogy and Higher School Pedagogy of Ivan Franko National University of Lviv, Candidate of Pedagogical Sciences

Мищишин Орест - доцент кафедри цифрової економіки та бізнес-аналітики Львівського національного університету імені Івана Франка, кандидат фізико-математичних наук, доцент

Myshchyshyn Orest - Assistant Professor of the Department of Digital Economics and Business Analytics of Ivan Franko National University of Lviv, Candidate of Physical and Mathematical Sciences, Associate Professor

\section{Цитуйте ию статтю як:}

Мищишин, I., Калагурка, X., \& Мищишин, O. (2020). Операційно-діяльнісні компетенції менеджера освіти. Педагогічний дискурс, 29, 70-75. doi: 10.31475/ped.dys.2020.29.09.
Cite this article as:

Myshchyshyn, I., $\quad$ Kalahurka, H.,
Myshchyshyn, O. $\quad$ (2020). Operating and Activity
Competence of the Education Manager. Pedagogical
Discourse, 29, 70-75. doi: 10.31475/ped.dys.2020.29.09.

